\title{
Autologous Anti-CD19 Chimeric Antigen Receptor T-cells SJCAR19
}

National Cancer Institute

\section{Source}

National Cancer Institute. Autologous Anti-CD19 Chimeric Antigen Receptor T-cells

SJCAR19. NCI Thesaurus. Code C142887.

A proprietary preparation of autologous T-lymphocytes that have been genetically modified to express a chimeric antigen receptor (CAR) targ eting the tumor-associated antigen (TAA) CD19 and containing, as of yet undisclosed, costimulatory signaling domains, with potential immunostimulating and antineoplastic activities. Upon administration, autolog ous anti-CD19 CAR T-cells SJCAR19 targ et and bind to CD19expressing tumor cells, thereby inducing selective toxicity in CD19-expressing tumor cells. CD19 antigen is a B-cell specific cell surface antigen expressed in all B-cell lineage malignancies. 